\title{
Open Access and Scholarly Communication: The Current Landscape, Future Direction, and the Influence on Global Scholarship
}

\author{
Daniel Gelaw Alemneh \\ Digital Libraries Services, \\ University of North Texas \\ Daniel.Alemneh@unt.edu
}

\author{
Samantha Hastings \\ School of LIS, University \\ of South Carolina \\ hastings@sc.edu
}

\author{
Suliman Hawamdeh \\ Department of LIS, COI \\ University of North Texas \\ Suliman.Hawamdeh@unt.edu
}

\author{
Austin McLean, \\ (ProQuest) ${ }^{1}$, and \\ Abebe Rorissa \\ $(\mathrm{SUNY})^{2}$
}

\begin{abstract}
The synergies of numerous emerging trends such as the development of open source software, global and explosive growth of social networking, interinstitutional data sharing, cross discipline collaborations, etc. provide new directions for scholarship. The rapid pace of development poses new threats and challenges to scholarly communication as well. Open access is increasingly viewed as a popular alternative to traditional distribution methods. Despite the overwhelming agreement regarding the concept of open access, there are however, significant differences and debate about a number of issues. This panel brings together diverse stakeholders, explores the current landscape and future direction of scholarly communication, and reflects on the overall implications on global scholarship.
\end{abstract}

\section{Keywords}

Open access, scholarly communication, digital libraries, global scholarship.

\section{INTRODUCTION}

The concept of open access essentially focuses on the need for the free exchange of knowledge and ensures the widest possible availability of scholarly literature and research documentation. In light of the prospects and challenges that this new environment brings, the participants on this panel discuss a number of issues from various perspectives:

This is the space reserved for copyright notices.

ASIST 2011, October 9-13, 2011, New Orleans, LA, USA Copyright notice continues right here.

\section{Knowledge Management Perspective}

Open access is increasingly viewed as a key to scientific knowledge sharing and scholarly communication especially with the rising cost of scientific journals and access controls as mandated by licensing arrangements. Dr. Suliman Hawamdeh is a Professor and Department Chair in the Department of Library and Information Sciences at the University of North Texas. He is an expert and a pioneer in the field of knowledge management. He will discuss the importance of open access in promoting knowledge sharing and best practices.

\section{Researchers' Perspective}

Dr. Abebe Rorissa is currently Assistant Professor in the Department of Information Studies at the University at Albany, State University of New York (SUNY). In light of the fact that scholars write to advance knowledge in their fields, Dr. Abebe will analyze how Open Access enhances the research impact and professional growth of the researchers. He will also discuss the economic and scholarly impact of open access in developing countries as well as the resistance to open access by the academic community.

\section{Digital Curators' Perspective}

Academic libraries provide services to support the creation, organization, management, use and reuse of digital scholarship. Dr. Daniel Gelaw Alemneh is a digital curator and project manager in the Digital Library Division of the University of North Texas Libraries. He will examine how the removal of barriers - (pricing, technical, and legal) facilitates the numerous activities required to maintain the digital assets of cultural heritage institutions.

\footnotetext{
1 Austin McLean, Director, Scholarly Communication and Dissertation Publishing, ProQuest, Ann Arbor, Michigan Email: Austin.McLean@proquest.com

${ }^{2}$ Abebe Rorissa, Associate Professor, Department of Information Studies, University at Albany, State University of New York (SUNY). Email: arorissa@albany.edu
} 


\section{Publishers' Perspective}

Open Access and the democratization of publishing has revolutionized publishing. Austin McLean is the Director of Scholarly Communication and Dissertation Publishing for ProQuest, Ann Arbor, Michigan. He implemented the world's first open access publishing model for monographs in 2006. He will share his insights into the current state of publishers' positions and opinions.

\section{University Administrators' and Editors' Perspectives}

Finally, Dr. Sam Hastings, (Director and Professor: School of Library and Information Science: University of South Carolina; and ASIS\&T monographs Editor) will uncover the pros and cons of the open access for LIS research and scholarly communication in general.

\section{REFERENCES}

Alemneh, D. \& Hastings, S. (2006). Developing the ICT Infrastructure for Africa: Overview of Barriers to Harnessing the Full Power of the Internet. Journal of Education for Library and Information Sciences, 47 (1) 4-16. Retrieved July 15, 2011 from: http://digital.library.unt.edu/ark:/67531/metadc38890/.

Crow, R. (2009). Campus-based Publishing Partnerships: A Critical Guide and Campus-based Publishing Resource
Center. SPARC [72-pp.]. Retrieved July 15, 2011 from http://www.arl.org/sparc/bm doc/pub_partnerships_v1.p df.

Herb, U. (2010). Sociological implications of scientific publishing: Open access, science, society, democracy, and the digital divide. First Monday, 15 (2). Retrieved July 15, 2011 from http:/firstmonday.org/htbin/cgiwrap/bin/ojs/index.php/f m/article/viewArticle/2599/2404.

King, D. (2010). An Approach to Open Access Author Payment. D-Lib Magazine 16 (3/4). Retrieved July 15, 2011 from http://www.dlib.org/dlib/march10/king/0.

Moen, W. \& Hartman, C. (2009). Open Access: A New Paradigm for Knowledge Creation, Dissemination, and Access. Retrieved July 15, 2011 from http://digital.library.unt.edu/ark:/67531/metadc32975/.

Morrison, H. (2007). Rethinking collections- Libraries and librarians in an open age: A theoretical view. First Monday, 12 (10). Retrieved July 15, 2011 from http://firstmonday.org/htbin/cgiwrap/bin/ojs/index.php/f m/article/viewArticle/1965/1841.

Waters, D., (2008). Open Access Publishing and the Emerging Infrastructure for 21st-Century Scholarship, Journal of Electronic Publishing, 11 (1). Retrieved July 15, 2011 from http://hdl.handle.net/2027/spo.3336451.0011.106. 